\title{
REPRODUCTION, FECUNDITY, AND GROWTH OF ABALONE (HALIOTIS TUBERCULATA COCCINEA, REEVE 1846) IN THE CANARY ISLANDS
}

\author{
AMAIA BILBAO,${ }^{1 *}$ VIICTOR TUSET,${ }^{2}$ MAPI VIERA, ${ }^{1}$ GERCENDE COURTOIS DE VICOSE, ${ }^{1}$ \\ HIPÓLITO FERNÁNDEZ-PALACIOS, ${ }^{1}$ RICARDO HAROUN ${ }^{3}$ AND MARISOL IZQUIERDO ${ }^{1}$ \\ ${ }^{1}$ Grupo de Investigación en Acuicultura. Universidad de Las Palmas de Gran Canaria e Instituto Canario \\ de Ciencias Marinas, PO Box 56, 35200, Telde, Las Palmas, Spain; ${ }^{2}$ Departamento de Biología Pesquera, \\ Instituto Canario de Ciencias Marinas, PO Box 56, 35200, Telde, Las Palmas, Spain; ${ }^{3}$ Center of \\ Biodiversity and Environmental Management, Faculty of Marine Sciences, University of Las Palmas de \\ Gran Canaria, 35017, Las Palmas, Spain
}

\begin{abstract}
The abalone, Haliotis tuberculata coccinea has been considered in the Canary Islands as a potential candidate species for aquaculture to restock its natural ecosystem. Because the study and development of artificial culture techniques require as much information as possible on natural populations, 20 monthly $H$. tuberculata coccinea samples were collected in the island of Gran Canaria between June 2005 and May 2007. Reproductive biology was assessed by histological techniques, and von Bertalanffy growth parameters were also estimated. Ovarian morphology of $H$. tuberculata coccinea showed 6 sexual cell stages during the oogenetic process and a group synchronous ovarian development. Its reproductive cycle is characterized by an annual spawning period throughout the entire year, although the maximum reproductive activity of this population was observed between August and February. Batch fecundity ranged from 85,749 (shell length (SL), $39 \mathrm{~mm}$ )-691,456 (SL, $62 \mathrm{~mm}$ ), and a significantly higher fecundity rate was observed in individuals with an SL larger than $55 \mathrm{~mm}$, suggesting that, to optimize egg production, this is the minimum broodstock size to be used in hatcheries. With regard to the population structure, the overall maleto-female ratio was 1:1.02 and the data of the size class analysis did not show any tendency. The von Bertalanffy growth parameters estimated for females and males were 72.5 and $78.8 \mathrm{~mm}$ in SL of asymptotic length, and 0.43 year $^{-1}$ and 0.37 year $^{-1}$ of growth rate.
\end{abstract}

KEY WORDS: abalone, oogenesis, spawning season, fecundity, growth, Haliotis tuberculata coccinea

\section{INTRODUCTION}

The reproductive seasonality of several abalone species from various regions in the world has been studied (Boolootian et al. 1962, Tomita 1967, Newman 1967, Webber \& Giese 1969, Poore 1970, Young \& DeMartini 1970, Hayashi 1980, Tutschulte \& Connell 1981, Capinpin et al. 1998, Fukazawa et al. 2007). Most of the studies mentioned here have contributed to the development and improvement of artificial propagation techniques for a number of abalone species, as well as to the growth of abalone aquaculture around the world (e.g., H. discus hannai and $H$. rufescens).

Ormer Haliotis tuberculata tuberculata Linnaeus (1758) is currently the only commercial abalone species in Europe. It was considered as a potential candidate for aquaculture development during the 1970s in France, and its commercial fishing and culture interest significantly increased throughout Europe during the early 1990s as a result of much easier international trade (rapid transport and market globalization) and an increase in its value in Asian markets (Huchette \& Clavier 2004). New practices for the production of juveniles have recently emerged and enabled a rapid expansion of this industry (Daume et al. 2004, Roberts et al. 2004). Ireland and the Channel Islands (Huchette \& Clavier 2004), Scotland (Kelly \& Owen 2002), and France are currently the only established producing countries. Spain has also carried out some experimental culture trials.

A subspecies of ormer, Haliotis tuberculata coccinea Reeve (1846), lives in the Macaronesian region (Geiger 2000). In the Canary Islands, it has a patchy distribution on exposed and

*Corresponding author: E-mail: abilbao@iccm.rcanaria.es semiexposed areas from low intertidal to subtidal depths, shallower than $15 \mathrm{~m}$, with an affinity for specific habitats (Núñez et al. 1994, Espino \& Herrera 2002). Coralline red algae are generally considered to provide an optimum substratum for larval settlement and metamorphosis (Morse \& Morse 1984). In fact, Espino and Herrera (2002) found high densities of $H$. tuberculata coccinea juveniles and adults on rock surfaces encrusted with coralline red algae. Furthermore, this habitat is closely linked to a regular supply of drifting algae carried by the currents. The amount of such drifting algae determines the abalone population density where its habitat is suitable (Clavier \& Chardy 1989).

This subspecies has been overexploited because of its high social and economic value. After Núñez et al. (1994) and Espino and Herrera (2002), it has been classified as an endangered species in the Catalogue of Threatened Species of the Canary Islands (BOC 2001). These studies have assessed some populations around the islands and concluded that this subspecies cannot withstand the fishing pressure in the Canaries. Recently, the government of the Canary Islands has shown interest in restocking this natural ecosystem and considered $H$. tuberculata coccinea as a new species for the diversification of local commercial aquaculture. Its artificial spawning induction was studied by Peña (1986) and, more recently, to improve knowledge about its culture, embryology, complete larval development, and juvenile nutrition requirements have also been described (Viera et al. 2005, Courtois de Vicose et al. 2007).

This study aims to provide more accurate biological information on sexuality, reproduction, fecundity, and growth of this species. This knowledge, when applied to hatchery-related activities, may improve the culture of this species and is essential to studying restocking in natural ecosystems. 


\section{MATERIALS AND METHODS}

\section{Sampling}

Monthly samples of 20 individuals were collected during the day by diving between June 2005 and May 2007 at a depth shallower than $10 \mathrm{~m}$ at El Castillo del Romeral Bay, Gran Canaria Island (Fig. 1). Total shell length (SL) to the nearest $0.5 \mathrm{~mm}$ and total body weight to the nearest $0.1 \mathrm{~g}$ were taken for each specimen. Conical appendages, consisting of the digestive gland and the surrounding gonad, were carefully removed and weighed to the nearest $0.001 \mathrm{~g}$.

\section{Ovary Morphology}

The basal, middle, and apical regions (Young \& DeMartini 1970 ) of the conical appendage was fixed in $10 \%$ buffered formaldehyde for histological study. After 24-48 h, they were dehydrated, embedded in paraffin wax, sectioned into crosssections (4-5 $\mu \mathrm{m}$ thick), and stained with Harris' hematoxylineosin stain. Three regions of conical appendages were observed microscopically to determinate the oogenetic processes in female gonads. Oocyte stages were assigned according to Apisawetakan et al. (2001)

\section{Sexuality and Spawning Season}

Sex and maturity stages of gonads were assigned according to the classification described by Capinpin et al. (1998) (Table 1). Monthly changes in the three following variables were analyzed to determine the spawning season (Hahn 1989):

1. Gonad bulk index (GBI) is the percentage of gonad tissue at the base of the conical appendage.
$\mathrm{GBI}=($ Area of the gonad in the section/Total area of the section $)$ $\times 100$

2. Percentage frequency of the maturity stages (EMS).

3. Oocyte diameter (OD): Diameters of 100 oocytes were measured using Image Proplus (ver. 5.0.1). Measurements were made only of oocytes sectioned through the nucleus.

\section{Fecundity}

The pattern of annual fecundity was assessed by oocyte size frequency distribution. Ripe females ranging from 37 to $47 \mathrm{~mm}$ in SL in the ripe stage were selected for analysis of oocyte size frequency distribution in November and March, representing gonad development early and late during the spawning season. Because the mean size ( $t$-test, $P>0.05$ ) was not significantly different between both samples, one frequency distribution was obtained for each month.

The gravimetric method was used to estimate batch fecundity (modified from Hayashi (1980)). Conical appendages of 12 ripe-stage females, collected in October, were isolated from gonads and weighed to the nearest $0.001 \mathrm{mg}$. Subsamples from 3 different locations (basal, middle, and apical regions) of each conical appendage were weighed, and oocytes loosened from trabeculae were counted. Fecundity was defined as the number of oocytes in stages 4 and 5 . To calculate the percentage of oocytes in each region, gonad was fixed in $10 \%$ buffered formaldehyde for histological study. Sections were photographed microscopically and 150 oocytes were identified in 2 groups: stages $1-3$ and stages $4-5$. Analysis of variance (ANOVA) was

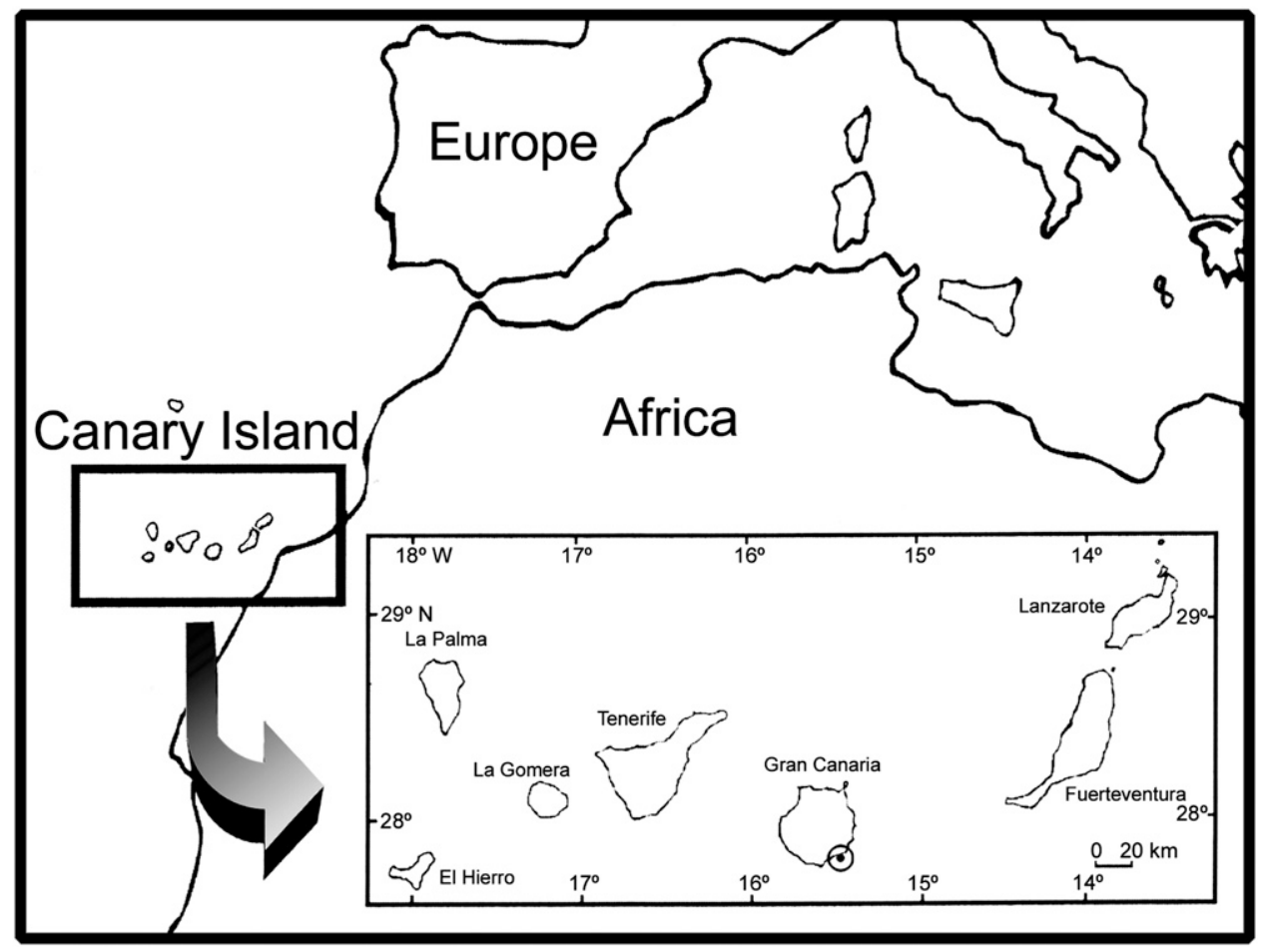

Figure 1. Location of sampling area of abalone specimens from the Canary Islands (eastern-central Atlantic). 
TABLE 1.

Criteria used to assess gonad development stage in $\mathrm{H}$. tuberculata coccinea (Capinpin et al. 1998).

\begin{tabular}{|c|c|}
\hline Stage & Description \\
\hline 1: Preproliferative & $\begin{array}{l}\text { The gonad is essentially immature and is characterized by little or no germinal epithelium between the } \\
\text { outer epidermis and the digestive gland. }\end{array}$ \\
\hline 2: Proliferative & $\begin{array}{l}\text { Spermatogonia cells are growing from the connective tissue tubules. Oogonia cells are growing from the } \\
\text { trabeculae and form clusters on trabecular walls. The gonad shows vacant spaces. }\end{array}$ \\
\hline 3: Maturing & $\begin{array}{l}\text { A layer of spermatids or spermatozoa is present in the testis. Vitellogenesis is initiated at this stage. } \\
\text { Early maturing ovary is characterized by newly stalked oocytes measuring about } 25 \mu \mathrm{m} \text {. A } \\
\text { late-maturing ovary has oocytes larger than } 50 \mu \mathrm{m} \text { that extend from the trabeculae toward } \\
\text { the digestive gland, with each attached by a stalk and is shaped like a teardrop. }\end{array}$ \\
\hline 4: Ripe & $\begin{array}{l}\text { The testis is densely packed with spermatozoa. A few early gametogenic stages may be present, but are } \\
\text { restricted around the tubules. The ovary has oocytes larger than } 150 \mu \mathrm{m} \text {. Mature oocytes free from } \\
\text { the trabeculae have a mean diameter of } 150 \mu \mathrm{m} \text {. A slight proliferation of oocytes less than } 25 \mu \mathrm{m} \text { is } \\
\text { common, especially near the peripheral wall of the gonad. }\end{array}$ \\
\hline 5: Partly spawned & $\begin{array}{l}\text { The testis has obvious spaces around the tubules where spermatozoa have vacated. Other areas appear } \\
\text { ripe. The ovary contains reduced densities of mature oocytes relative to ripe gonads. The gonad lumen } \\
\text { is partially collapsed with folded trabeculae. A moderate number of ripe oocytes still present in some } \\
\text { areas is densely packed. }\end{array}$ \\
\hline 6: Spent & $\begin{array}{l}\text { A spent gonad is characterized by lack of ripe gametes and slight gametogenic activity. Macroscopically, } \\
\text { the gonad is greatly reduced. The gonad lumen is collapsed, with folded trabeculae or tubules. } \\
\text { A spent ovary may have few residual oocytes. }\end{array}$ \\
\hline
\end{tabular}

used to compare the relative frequency (number oocytes per gonad area) in the sample areas of conical appendage.

The females were divided into 3 classes according to their shell length (35-44, 45-54, and 55-64 mm) and the batch fecundity results were submitted to a statistical analysis applying a 1-way ANOVA followed by a Tukey test for multiple comparisons of means, at a $5 \%$ significance level $(P<0.05)$.

\section{Population Structure}

Normality of length data was previously determined by means of the Kolmogorov-Smirnov test for comparing the mean sizes of the different study groups of abalone. The same statistical test was used for comparing different distributions of length data. Student's $t$-test was applied as a nonparametric test for comparing 2 means (Zar 1996). Carapace length-per-wet weight relationships were calculated on each sex or group with respect to the whole period studied.

The overall ratio (males to females) and the sex ratios by size intervals $(2 \mathrm{~mm})$ were determined considering the number of males and females. Sex ratios were tested statistically for significant deviations from the expected 1:1 ratio with a chisquare test $(P>0.05)$.

\section{Growth}

Length frequency data were analyzed for estimating growth in each sex by means of Pauly's method (Pauly 1983). Length frequency was represented quarterly during 2 y to simulate the time sequence. The FAO-ICLARM Stock Assessment Tools (FISAT) program (version 1.2) was used for data processing and calculating the von Bertalanffy growth parameters. Bhattacharya's method was used for decomposition of mixtures of normal distribution. The estimation of $L_{\infty}$ was obtained by means of Gulland and Holts' method, whereas the $k$ value was determined using the routine ELEFAN I (Gayanilo \& Pauly 1997). For the sake of comparison, growth performance of both sexes Munro's phi prime $\left(\varphi^{\prime}=\log k+2 \log L_{\infty}\right)$ was assessed according to Sparre et al. (1989).

\section{RESULTS}

\section{Ovary Morphology}

The histological study revealed that the conical appendage included the conical digestive gland surrounded by the ovary, which was classified into 3 regions according to the relative importance of both tissues. In the basal region the digestive gland occupied most of the cross-section, in the medium region the ovary filled most of the cross-section, and in the apical region only ovarian tissue was found. The ovary was enclosed within 2 walls that separated the ovary from the mantle and the digestive gland. The connective tissue extended perpendicularly into the gonads to generate the trabeculae, dividing the gonad into compartments around the lumens, where oocytes were developing. The first stages of the sexual cells appeared attached to the trabeculae, whereas mature oocytes were formed near the lumen. The trabeculae decreased in thickness as the female gonad ripened. Two phases and 6 stages of female sexual cells were recognized (Fig. 2).

\section{Previtellogenic Phase}

Oogonia $(\mathrm{Og})$ : round cells $10.66 \pm 2.7 \mu \mathrm{m}$ in diameter, closely attached to the trabeculae, showing a highly basophilic nucleus surrounded by homogeneous basophilic cytoplasm (Fig. 2A)

Stage 1 oocyte $(\mathrm{Oc} 1)$ : oval shaped with a maximum diameter of $26.47 \pm 6.44 \mu \mathrm{m}$ and a minimum diameter of $15.48 \pm 4.05 \mu \mathrm{m}$, strongly attached to the trabeculae, round nucleus containing a diffuse nuclear envelope, follicular cells surrounding (Fig. 2B)

Stage 2 oocyte (Oc2): elongated shaped with maximum diameter of $60.51 \pm 17.32 \mu \mathrm{m}$ and a minimum diameter of $33.15 \pm$ $13.04 \mu \mathrm{m}$, attached to the trabeculae only in the basal region, oval nucleus, first lipid droplets appear (Fig. 2B, C). 

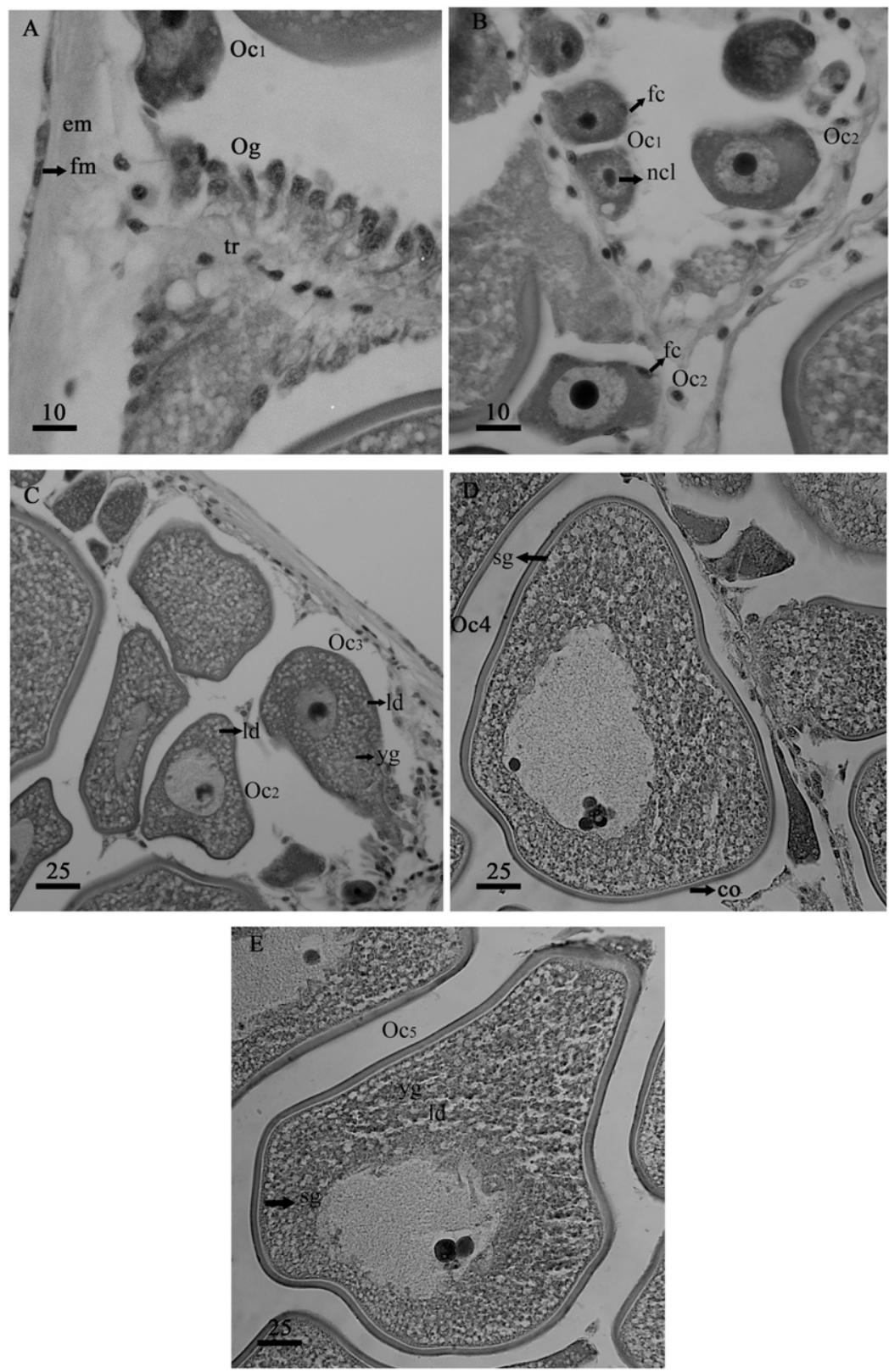

Figure 2. Slides of ovarian $\mathrm{H}$. tuberculata coccinea tissue stained with hematoxylin-eosin. (A) Oogonia $(\mathrm{Og})$ attached to the capsular side of the trabeculae (tr). Ovarian epithelium (em) shows fibromuscular cells $(\mathrm{fm})$. (B) Oc1 contains an intense basophilic cytoplasm and a prominent nucleolus (ncl), surrounded by follicular cells (fc). Oc2 shows a clear nuclear envelope. (C) Oc2 shows the lipid droplets (ld). Oc3 shows the first eosinophilic yolk granules (yg). (D) Oc4 shows the secretory granules (sg) migrating toward the cell peripheries. A thin layer of homogenous jelly coat (co) recovers the outer surface of the cell membrane. (E) Oc5 is surrounded by a uniformly thick jelly coat and is not attached to the trabeculae.

\section{Vitellogenic Phase}

Stage 3 oocyte (Oc3): pear shaped with a maximum diameter of $110.30 \pm 27.63 \mu \mathrm{m}$ and a minimum diameter of $59.64 \pm 21.02$ $\mu \mathrm{m}$, increasing number of lipid droplets, appearance of first yolk eosinophilic vacuoles (Fig. 2C)

Stage 4 oocyte (Oc4): polygonal shaped with a maximum diameter of $162.25 \pm 28.76 \mu \mathrm{m}$ and a minimum diameter of $103.2 \pm 23.49$ $\mu \mathrm{m}$, attached to the trabeculae by a small contact surface, cytoplasm contains yolk vacuoles and numerous lipid droplets, secretory granules with basophilic propriety migrate toward the plasma membrane, follicular cells located around the narrowest part of the cell, appearance of a thin eosinophilic layer of jelly coat on the outer surface of the cell membrane (Fig. 2D)

Stage 5 oocyte (Oc5): polygonal shaped with a maximum diameter of $171.77 \pm 28.75 \mu \mathrm{m}$ and a minimum diameter of $114.91 \pm$ $26.51 \mu \mathrm{m}$, oocyte is released into the lumen of the ovary, follicular cells absent, yolk vacuoles aggregated (Fig. 2E).

\section{Sexuality and Spawning Season}

Of the total number of abalone examined, 207 were female and 204 were male. Assignation of sex macroscopically was easy in most cases, except in the smaller or spent gonads. 
Maturing and ripe-stage gonads were found throughout the study period, except July, with maximum ripeness for both sexes noted in November (60\%; Fig. 3). Partly spawned and spent-stage individuals appeared yearlong, excluding January, probably because of the few number of samples $(n=11$ over $2 \mathrm{y})$.

The changes of GBI measured at the base of the conical appendage are shown in Figure 4. The highest values were observed between August and February, whereas the GBI decreased between February and May.

The oocyte diameter (Fig. 5) indicated a similar trend to GBI, with the highest values noted between August and February and lowest values noted between March and July.

The results described here suggest an annual reproductive cycle, spawning throughout the year, although, in general, maximum activity took place between August and February.

\section{Batch Fecundity}

Oocyte size frequency distributions showed 2 populations of oocytes (Fig. 6), indicating a group synchronous ovaric development. Approximately $78 \%$ of oocytes observed were in stage 4 or stage 5 . Bach fecundity ranged from 85,749 (SL, 39 $\mathrm{mm})-691,456$ oocytes (SL, $62 \mathrm{~mm}$ ), with a mean of $391,103 \pm$ 275,257 oocytes. A positive association was found between fecundity and SL $\left(r^{2}=0.924\right)$ and wet body weight $\left(r^{2}=0.869\right.$; Fig. 7). Tukey's test revealed significant differences $(P<0.05)$ in the mean fecundity of the highest size class (SL, 55-64 mm; Fig. 8).

\section{Population Structure}

Females ranged from 29-72 $\mathrm{mm}$ in SL and between $2.87 \mathrm{~g}$ and $57.85 \mathrm{~g}$ in weight; males varied from $26-75 \mathrm{~mm}$ in SL and between $1.73 \mathrm{~g}$ and $66.30 \mathrm{~g}$ in weight. Student's $t$-test showed significant differences in size between sex $(P<0.01)$ and the Kolmogorov-Smirnov test also indicated differences in size distribution $(P<0.05$; Fig. 9). Analysis of covariance $(\mathrm{F}=$ 5.164, $P=0.018$ ) noted significant differences by sex in the relationship of size to weight (Fig. 10).

The overall ratio of males to females was $1: 1.02$, so the hypothesis that the sex ratio was 1:1 must be accepted (chisquare $=0.022, P=0.882$ ). The analysis by size class did not reveal a tendency in data.

\section{Growth}

The parameters of the von Bertalanffy growth equation estimated for females and males were $72.5 \mathrm{~mm}$ and $78.8 \mathrm{~mm}$ in SL of asymptotic length and $0.43 / y$ and $0.37 / y$ of growth rate, respectively. The growth performance index $\varphi^{\prime}$ was very similar in both sexes: 3.35 in females and 3.36 in males.

\section{DISCUSSION}

Reproduction is an important aspect for the aquaculture of new species. To understand abalone reproduction better, the morphology of sexual cells during the oogenetic process has been studied for different abalone species, such as $H$. discus hannai (Tomita 1967, Awaji \& Hamano 2004, Fukazawa et al. 2007), H. rufescens (Young \& DeMartini 1970, Martin 1983),
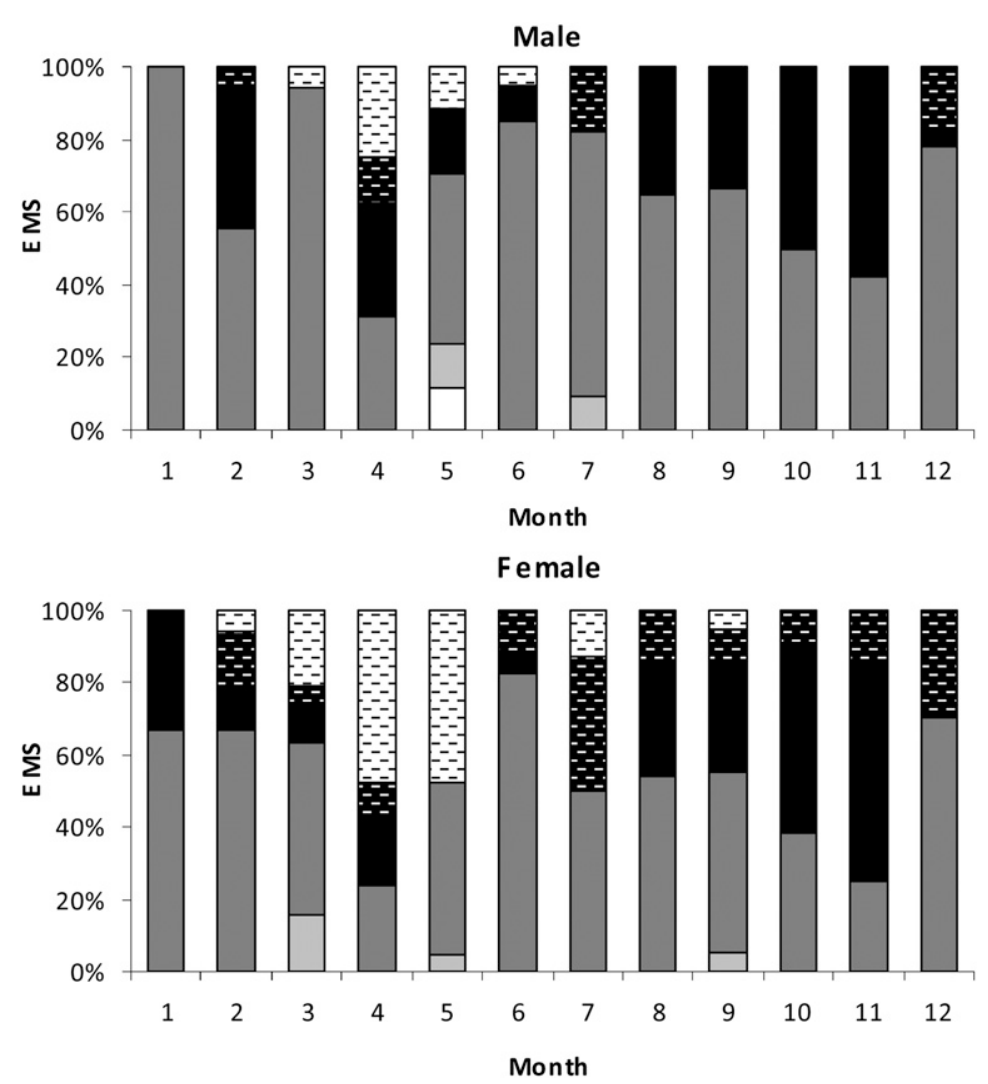

Figure 3. Monthly changes in the percent frequency of the maturity stages (EMS) for males and females. $\square$, Pre-proliferative; $\square$, Proliferative;

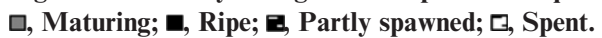




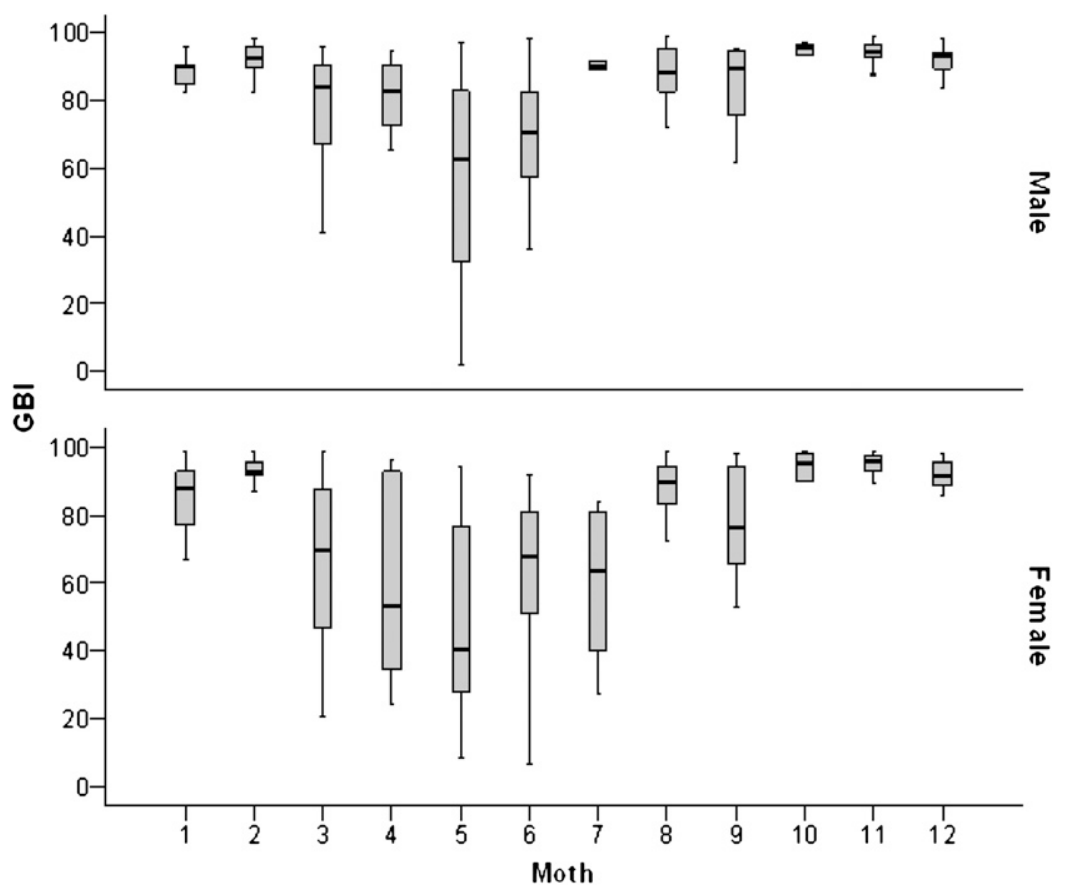

Figure 4. Seasonal variation of the gonad bulk index (GBI) box plot.

H. diversicolor (Takashima 1978), H. asinina (Apisawetakan et al. 2001), and H. tuberculata coccinea (current study). These studies have proved that the gonadal structure of various abalone species is very similar. It has been also reported that oocyte development is group synchronous, observing a cohort of large oocytes and another of smaller ones (Tomita 1967, Jebreen et al. 2000, Fukazawa et al. 2007; current study). These studies suggest that vitellogenic oocytes are expelled under favorable environmental conditions, whereas small cohorts of oocytes are kept in the ovarian tissues until the next spawning. However, the time elapsed between different spawning events in $H$. tuberculata coccinea is still unknown. Tropical abalone $H$. asinina is able to develop oocyte cohorts at least 3 times a year (Jebreen et al. 2000), whereas H. discus hannai develop oocyte cohorts twice a year (Fukazawa et al. 2007). With regard to $H$. tuberculata coccinea populations in the Canary Islands,

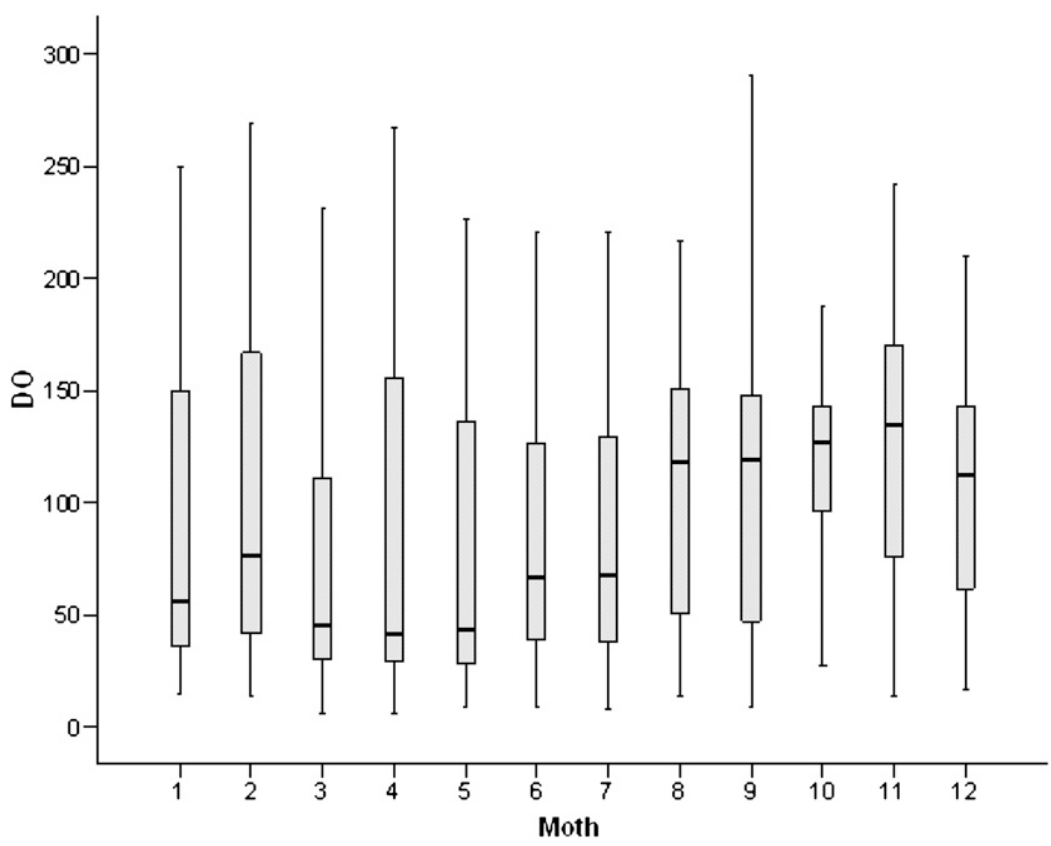

Figure 5. Seasonal variation of the oocytes diameter (DO) box plot. 


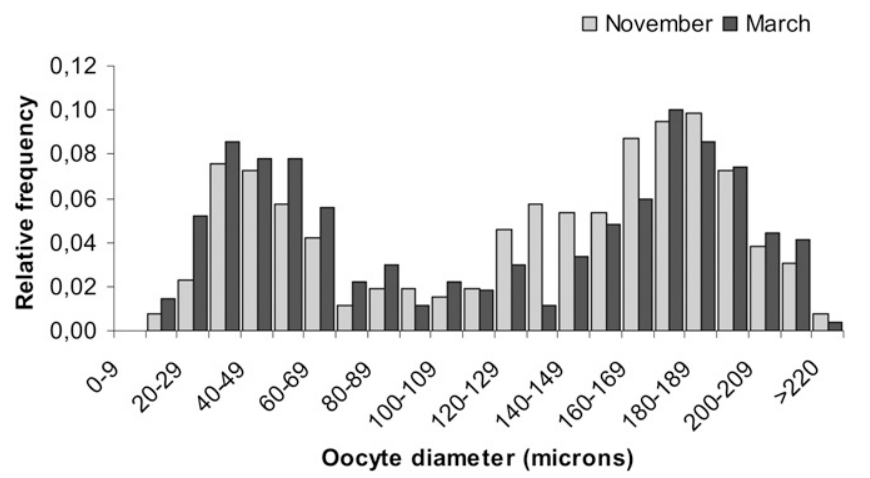

Figure 6. Oocyte size frequency distributions in ripe gonads representing gonad development early (November) and late (March) during the spawning season.

the high values of GBI and oocyte diameter throughout the year indicate that spawning occurs yearlong. Therefore, these species can be described as partial-spawning species.

The comparative analysis of $H$. tuberculata sp. spawning seasons suggests an increase in spawning periods depending on latitude. Hayashi (1980) found that northern populations in the British Channel spawned over short periods, whereas southern populations spawned twice a year or extended the reproductive season. Likewise, H. midae, a species found in South Africa, spawns for a short period of time between October and December (Newman 1967). In the Canary Islands, a subtropical region, the spawning season for $H$. tuberculata coccinea occurs throughout the year, with peak activity between August and
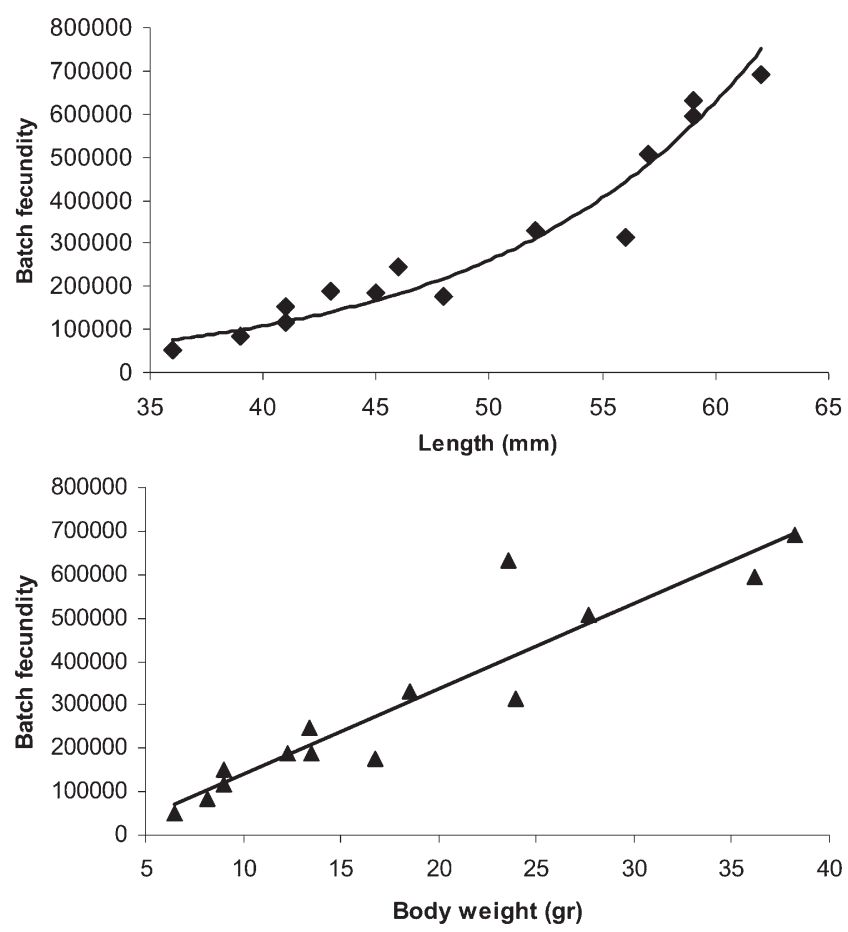

Figure 7. Relationships between batch fecundity and shell length and body weight. The equation for shell length is $\mathrm{F}=3187 \mathrm{e}^{0.0881 \times \mathrm{SL}}\left(r^{2}=0.924\right)$ and for body weight is $\mathrm{F}=19,546 \mathrm{BW}-53,497\left(r^{2}=0.8696\right)$, where $\mathrm{F}$ is fecundity, $\mathrm{SL}$ is shell length in millimeters, and $\mathrm{BW}$ is body weight in grams.

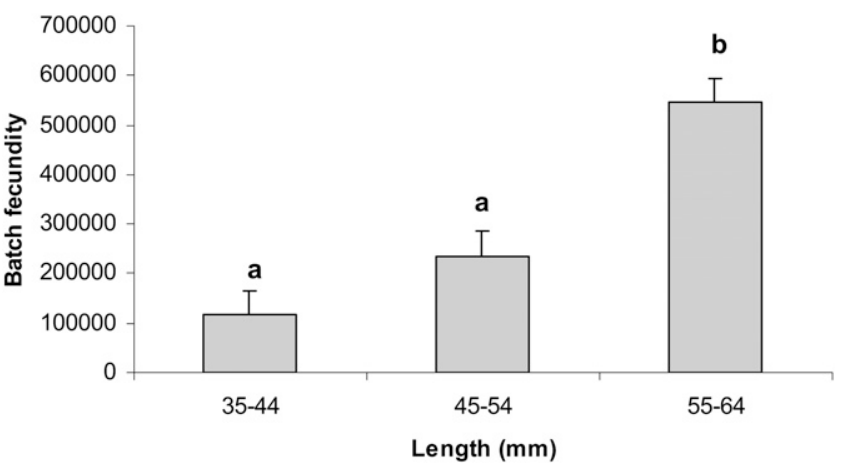

Figure 8. Batch fecundity according to shell length of ripe females. Vertical bars indicate SEM. The number of oocytes per female of 55-64 $\mathrm{mm}$ is significantly higher $(P<0.05)$ than that for females of $45-54 \mathrm{~mm}$ and $35-44 \mathrm{~mm}$ in shell length.

February. Temperature seems to be the most important factor affecting reproduction (Newman 1967, Girard 1972, Hayashi 1980, Uki \& Kikuchi 1984, Counihan et al. 2001). In the Canaries, the water temperature increase (Fig. 11) starts in August $\left(>20^{\circ} \mathrm{C}\right)$, when gonad development in the majority of the individuals in the population is observed. However, this reproductive behavior is maintained throughout the year, and this may be related to spring tides around new or full moons (experimental observation under culture conditions). Similarly, Jebreen et al. (2000) observed that ovulation and spawning in a natural population of $H$. asinina, a tropical species, are also associated with spring tides. Counihan et al. (2001), according to experiments performed with this species under captivity conditions, suggest that tidal elements influence the spawning biology, maintaining endogenous rates that persist in nontidal environments (e.g., aquaculture installations) for at least $6 \mathrm{wk}$; after this period, spawning continues, although irregularly.

It is difficult to carry out comparisons of fecundity estimations among species and studies because the methodology used varies greatly. Some studies are based on artificial spawning

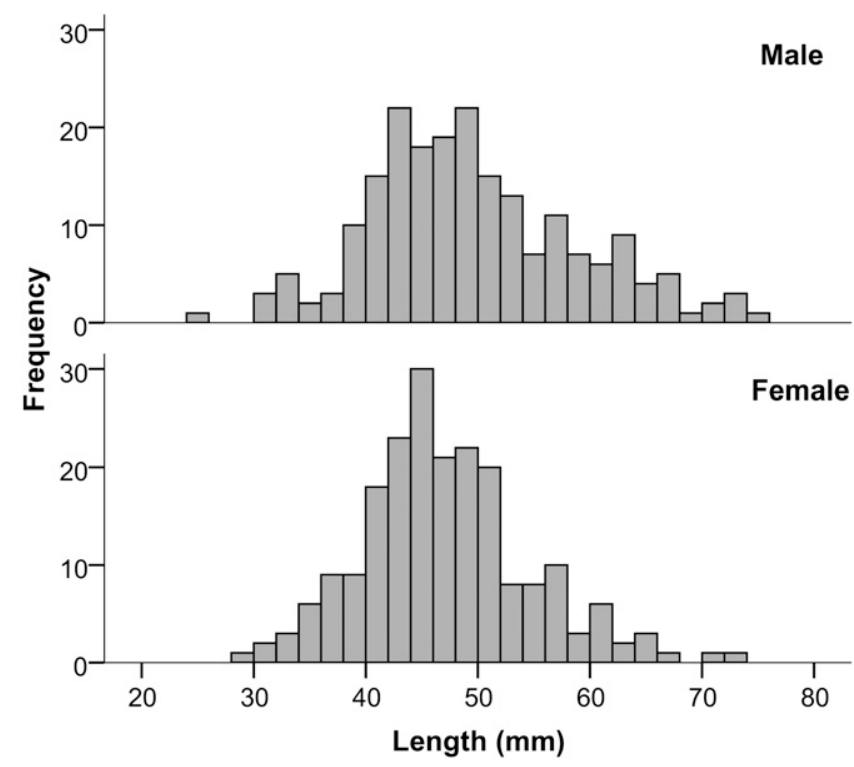

Figure 9. Size frequency distribution by sex. 

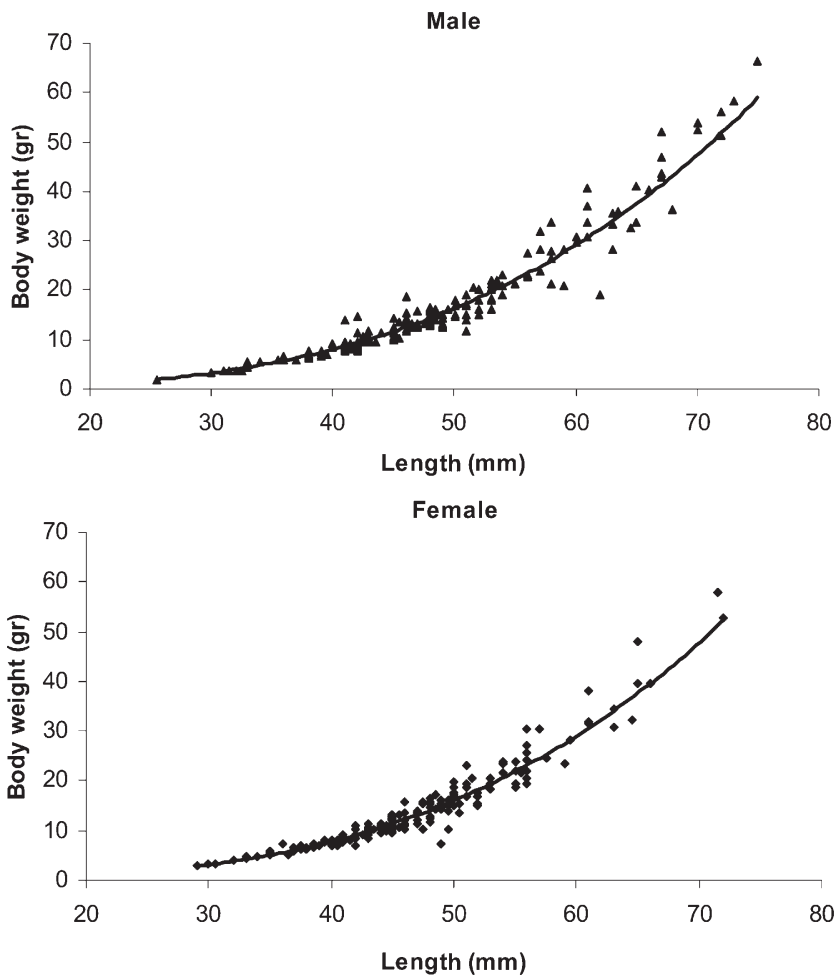

Figure 10. Length-weight relationship for males $(n=204)$ and females $(n=207)$. The power equations are $\mathrm{BW}=6.6 \times 10^{-5} \times \mathrm{SL}^{3.173}\left(r^{2}=\right.$ $0.959)$ for males and $\mathrm{BW}=5.1 \times 10^{-5} \times \mathrm{SL}^{3.23}\left(r^{2}=0.953\right)$ for females, where $\mathrm{BW}$ is body weight and SL is shell length.

induction (Peña 1986, Clavier 1992), whereas others are based on rearing animals from natural population and on counting the eggs released during natural spawning (Capinpin et al. 1998). Other studies are performed by the identification of mature oocytes according to their size or morphological features, calculating the fecundity based on gonad weight or volume (Hayashi 1980, Tutschulte \& Connell 1981, Rogers-Bennett et al. 2004). The data from the current study provide a higher fecundity value than that obtained by Peña (1986), who carried out experiments in $H$. tuberculata coccinea populations with animals collected in the Canary Islands at temperatures between $15.3^{\circ} \mathrm{C}$ and $17.5^{\circ} \mathrm{C}$ (probably low for complete gonadal maturation). However, a comparison with other similar-size abalone,

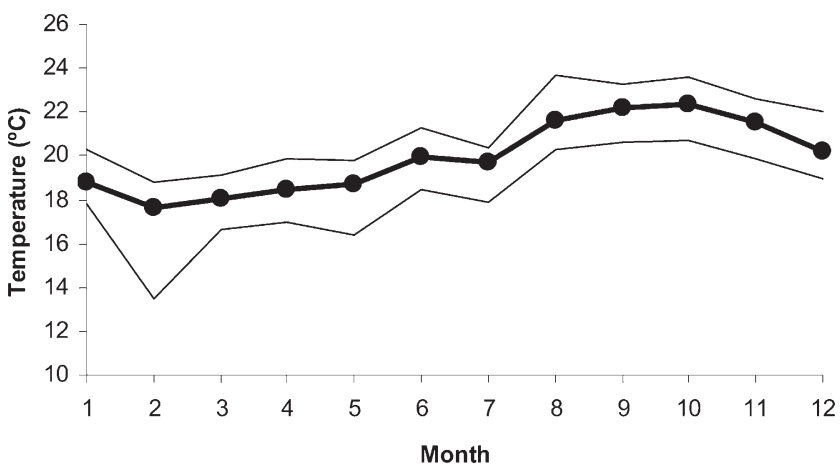

Figure 11. Means of surface water temperature in Castillo del Romeral Bay. The upper and lower lines indicate the maximum and minimum temperatures. such as $H$. asinina, reveals similar fecundity estimations: 150,000 600,000 eggs (SL, 58.1-69 mm) (Capinpin et al. 1998). Furthermore, it has been found that abalone fecundity increases as SL and body weight increase (Newman 1967, Hayashi 1980, Clavier 1992, Littay \& DeSilva 2003; current study).

With regard to the population structure - in other words, the sex ratio - the data found were similar to those obtained for other abalone species such as $H$. cracherodii, $H$. rufescens, and H. midae (Boolootian et al. 1962, Newman 1967). The biggest specimen size reported for wild $H$. tuberculata coccinea populations was $70 \mathrm{~mm}$ in SL (Núñez et al. 1994), smaller than the size observed in our study (SL, $75 \mathrm{~mm}$ ). The size of this species is similar to the size of other warm-water species such as $H$. diversicolor supertexta. However, other species of culture interest such as $H$. tuberculata tuberculata, $H$. discus hannai, and H. rufescens reach higher sizes of 120, 200, and $275 \mathrm{~mm}$ in SL, respectively (Hahn 1989). Accordingly, the different maximum SLs observed in abalone species suggest variations in the growth parameters. The results obtained in this study showed similar values of $k(0.37-0.43 / \mathrm{y}$ and $0.25-0.45 / \mathrm{y}$, respectively) and a lower value of $L_{\infty}$ (SL, 72.50-78.8 mm and 99-119 mm, respectively) (Day \& Fleming 1992). We consider that, in cold waters, the short spawning periods favor the energy supplies for growing up, whereas, in warm waters where spawning periods are longer, most energy is used for reproductive purposes.

The knowledge gained with this study may be useful in $H$. tuberculata coccinea hatcheries. The ability to have mature individuals throughout the year or at predictable times will allow aquaculturists to schedule hatchery processes during periods that are more favorable for growth and survival (Hahn 1989). Therefore, the culture of this species requires the conditioning of broodstock from the late summer until early winter, when the populations showed a higher maturity rate. Hence, the gonadal maturation of some warm-water abalone species respond to temperature changes (Leighton et al. 1981, Morse 1984, Hooker $\&$ Morse 1985). It would be interesting to study the conditioning of $H$. tuberculata coccinea broodstock from late winter until spring by raising them in seawater at a temperature between $18^{\circ} \mathrm{C}$ and $22^{\circ} \mathrm{C}$. Furthermore, the significantly higher fecundity rates found in individuals larger than $55 \mathrm{~mm}$ in SL suggest that, to optimize egg production, this is the minimum broodstock size that should be used in commercial hatcheries.

\section{ACKNOWLEDGMENTS}

We thank Mr. Raico García for the collection of samples and the Department of Oceanography of ICCM for providing the temperature data. This research was supported by Innova Grant (University of Las Palmas de Gran Canaria) awarded to A. B. and the JACUMAR Project (ref. 55172) titled Cultivo y Gestión de la Oreja de Mar.

\section{LITERATURE CITED}

Apisawetakan, S., V. Linthong, C. Wanichanon, S. Panasophonkul, A. Meepool, M. Kruatrachue, E. S. Upatham, T. Pumthong \& P. Sobhon. 2001. Ultrastructure of female germ cells in Haliotis asinina Linnaeus. Invertebr. Reprod. Dev. 39:67-79.

Awaji, M. \& K. Hamano. 2004. Gonad formation, sex differentiation and gonad maturation processes in artificially produced juveniles of the abalone, Haliotis discus hannai. Aquaculture 239:397-411. 
BOC 2001/097. Official Gazette of the Canary Islands (2001/097) published on August 1, 2001. Royal Decree 151/2001 of 23 July 2001, which approves the Catalogue of Threatened Species of the Canary Islands.

Boolootian, R. A., A. Farmanfarmaian \& A. C. Giese. 1962. On the reproductive cycle and breeding of two western species of Haliotis. Biol. Bull. Marine Biol. Lab., Woods Hole, Mass. 122:183-193.

Capinpin, E., V. Encena \& N. Bayona. 1998. Studies on the reproductive biology of the donkey's ear abalone, Haliotis asinina Linné. Aquaculture 166:141-150.

Clavier, J. 1992. Fecundity and optimal sperm density for fertilization in the omer (Haliotis tuberculata L.). In: S. A. Guzman del Proo, M. J. Tegner \& S. A. Shepherd, editors. Abalone of the world. Adelaide: Fishing News Books. pp. 86-92.

Clavier, J. \& P. Chardy. 1989. Investigation into the ecology of the ormer (Haliotis tuberculata L.), factors influencing spatial distribution. Aquat. Living Resour. 2:191-197.

Counihan, R. T., D. C. McNamara, D. C. Souter, E. J. Jebreen, N. P. Preston, C. R. Johnson \& B. M. Degman. 2001. Pattern, synchrony and predictability of spawning of the tropical abalone, Haliotis asinina from Heron Reef, Australia. Mar. Ecol. Prog. Ser. 213:193-202.

Courtois de Vicose, G., M. P. Viera, A. Bilbao \& M. S. Izquierdo. 2007. Embryology and complete larval development of Haliotis tuberculata coccinea R.: an index microphotographic sequence. J. Shellfish Res. 26:847-854.

Daume, S., S. Huchette, S. Ryan \& R. W. Day. 2004. Nursery culture of Haliotis rubra: the effect of cultured algae and larval density on settlement and juvenile production. Aquaculture 236:221-239.

Day, R. W. \& A. E. Fleming. 1992. The determinants and measurement of abalone growth. In: S. A. Guzman del Proo, M. J. Tegner \& S. A. Shepherd, editors. Abalone of the world. Adelaide: Fishing News Books. pp. 141-167.

Espino, F. \& R. Herrera. 2002. Seguimiento de poblaciones de especies amenazadas 2002 (Haliotis tuberculata coccinea, Nordsieck, 1975) Gran Canaria. Final report prepared by Glesplan and the Ministry of Planning and Environment of Gran Canaria. Unpublished report. $52 \mathrm{pp}$.

Fukazawa, H., T. Kawamura, H. Takami \& Y. Watanabe. 2007. Oogenesis and relevant changes in egg quality of abalone Haliotis discus hannai during a single spawning season. Aquaculture 270:265275.

Gayanilo, F. C. Jr. \& D. Pauly. 1997. The FAO-ICLARM Stock Assessment Tool (FISAT). Reference manual. FAO computerized information series (fisheries), no. 8. Rome: FAO. 262 pp.

Geiger. 2000. Distribution and biogeography of the recent Haliotidae world wide. Bull. Malacol. 35:57-188.

Girard, A. 1972. La reproduction de l'ormeau, Haliotis tuberculata L. Rev. Trav. Inst. Pêches Marit. 36:163-184.

Hahn, K. O. 1989. Gonad reproductive cycles of abalone. In: K. O. Hahn, editor. Handbook of culture of abalone and other gastropods. Boca Raton, FL: CRC Press. pp 13-39.

Hayashi, I. 1980. The reproductive biology of the ormer, Haliotis tuberculata. J. Mar. Biol. Assoc. UK 60:415-430.

Hooker, N. \& D. E. Morse. 1985. Abalone: the emerging development of commercial cultivation in the United States. In: J. V. Huner \& E. E. Brown, editors. Crustacean and Mollusc Aquaculture in the United States. AVI Publisher, Westport: 365-413.

Huchette, S. M. H. \& J. Clavier. 2004. Status of the ormer (Haliotis tuberculata L.) industry in Europe. J. Shellfish Res. 23: 951-955.

Jebreen, E., T. Counihan, D. Fieldder \& B. Degnan. 2000. Synchronous oogenesis during the semilunar spawning cycle of the tropical abalone Haliotis asinina. J. Shellfish Res. 19:845-851.

Kelly, M. S. \& P. V. Owen. 2002. Growth of the abalone Haliotis tuberculata L. at Scottish sea temperatures. Aquacult. Res. 33:729-733.
Littay, M. \& S. DeSilva. 2003. Spawning season, fecundity and proximate composition of the gonads of wild-caught blacklip abalone (Haliotis rubra) from Port Fairy waters, south eastern Australia. Aquat. Living Resour. 16:353-361.

Leighton, D. L., M. Byhower, J. C. Kelly, G. N. Hooker \& D. E. Morse. 1981. Acceleration of development and growth in young green abalone (Haliotis fulgens) using warmed effluent seawater. J. World Maricult. Soc. 12:170.

Martin, G. C. 1983. Fine structure of the ovary in the red abalone Haliotis rufescens (Mollusca: Gastropoda). Zoomorphology 103:89102.

Morse, D. E. 1984. Biochemical and genetics engineering for improved production of abalones and other valuable mollusc. Aquaculture 39:263.

Morse, A. D. \& D. E. Morse. 1984. Recruitment and metamorphosis of Haliotis larvae induced by molecules uniquely available at the surface of crustose red algae. J. Exp. Mar. Biol. Ecol. 75:191215.

Newman, G. C. 1967. Reproduction of the South African abalone Haliotis midae. Invest. Rep. Div. Sea Fish, S. Afr. 64: 1-24.

Núñez, J., M. Barquín \& A. Brito. 1994. Cartografía de la distribución, biología y evaluación de los recursos marisqueros de moluscos litorales canarios: lapas, orejas de mar y mejillón. $1^{\circ}$ fase. La Palma, Tenerife, Gran Canaria y Fuerteventura. Final report prepared by the Department of Animal Biology, University of La Laguna (Spain). Unpublished report. 323 pp.

Pauly, D. 1983. Length-converted catch curves: a powerful tool for fisheries research in the tropics (part I). Fishbyte. 1:9-13.

Peña, J. 1986. Preliminary study on the induction of artificial spawning in Haliotis coccinea canariensis Nordsieck (1975). Aquaculture 52:35-41.

Poore, G. C. B. 1970. Ecology of New Zealand abalones Haliotis species (Mollusca: Gastropoda) 4. Reproduction. N. Z. J. Mar. Freshw. Res. 7:67-84.

Roberts, R. D., H. F. Kaspar \& R. J. Barker. 2004. Settlement of abalone (Haliotis iris) larvae in response to five species of coralline algae. J. Shellfish Res. 23:975-987.

Rogers-Bennett, L., R. F. Dondanville \& J. Kashiwada. 2004. Size specific fecundity of red abalone (Haliotis rufescens): evidence for reproductive senescence? J. Shellfish Res. 23:553-560.

Sparre, P., E. Ursin \& S. C. Venema. 1989. Introduction to tropical fish stock assessment. Part 1. Manual. FAO Fish. Tech. Pap. 306(1):1-337.

Takashima, F. 1978. Gametogenesis and reproductive cycle in Haliotis diversicolor Reeve. J. Tokyo Univ. Fish. 1:1-8.

Tomita, K. 1967. The maturation of the ovaries of the abalone, Haliotis discuss hannai Ino, in Rebun Island, Hokkaido, Japan. Sci. Rep. Hokkaido Fish. Exp. Stn. 7:1-17.

Tutschulte, T. C. \& J. H. Connell. 1981. Reproductive biology of three species of abalone (Haliotis) in southern California. Veliger 23:195206.

Uki, N. \& S. Kikuchi. 1984. Regulation of maturation and spawning of an abalone, Haliotis (Gastropoda) by external environmental factors. Aquaculture 39:247-261.

Viera, M. P., J. L. Gómez-Pinchetti, G. Courtois de Vicose, A. Bilbao, S. Suárez, R. J. Haroun \& M. Izquierdo. 2005. Suitability of three red macroalgae as a feed for the abalone Haliotis tuberculata coccinea Reeve. Aquaculture 248:75-82.

Webber, H. H. \& A. C. Giese. 1969. The reproductive cycle and gametogenesis in the black abalone Haliotis cracherodii (Gastropoda: Prosobranchiata). Mar. Biol. 4:152-159.

Young, J. \& J. DeMartini. 1970. The reproductive cycle, gonad histology and gametogenesis of the red abalone, Haliotis rufescens (Swainson). Calif. Fish Game 56:298-309.

Zar, J. H. 1996. Biostatistical analysis, 3rd edition. Englewood Cliffs, NJ: Prentice-Hall International. 662 pp. 